\title{
Arkansas Governors in the Twentieth Century: a Ranking and Analysis
}

Cal Ledbetter, Jr.

University of Arkansas at Little Rock

C. Fred Williams

University of Arkansas at Little Rock

Abstract: Some forty-one individuals selected for their knowledge of Arkansas government and history participated in a poll in which they were asked to rank Arkansas governors from 1900 to 1970 in categories ranging from great to poor. Although not one of the sixteen governors was ranked as great, those securing the highest ranking were activist governors with a reformist orientation, and in this sense, the results were similar to those obtained by Arthur S. Schlesinger and others when Presidents of the United States were evaluated by experts on the Presidency. Respondent comments on each governor are summarized and there is also a brief treatment of each governor and the historical period during which he held office.

Despite the fact that the office of the American Presidency was modeled somewhat along the lines of the of fice of governor in New York state, the Presidency has consistently overshadowed the state office that helped give it birth. It is certainly not surprising that the President receives more attention than governors, given the power and scope of the office, its leadership role in foreign affairs, and the function of the office in symbolizing the country's history and greatness. The of fice of governor in most states lacks the potential for political drama found in the Presidency and, in addition, is burdened with legal handicaps not experienced by the Presidency, such as independently elected executives at the state level (a check and balance system 
within one branch of government) and state agencies with varying degrees of autonomy. In fact, the change is now so complete that many reformers at the state level now attempt to remodel the office of state governor along Presidential lines.

Because the Presidency throughout American history has held the attention of both the public and academics, there are periodic attempts to poll experts and ask them to rank Ameri-" can Presidents in categories ranging from "great" to "failure." Broad standards of evaluation are usually provided to help the experts measure achievement in the executive office, and the Presidents are usually ranked in order from the one who is ranked as the greatest through the one who is deemed to be the worst. The most famous polls of this nature were those done by Arthur M. Schlesinger, Sr., in 1948 and 1962. Although any poll of this kind is bound to be subjective and relatively unscientific, it can provide some measurement of historical judgment at a particular moment in time and can be useful for comparison purposes in the future. Nevertheless, polls that rank chief executives seem to be confined to Presidents, and the purpose of this article is to use the Schlesinger approach to rank state governors.

It is hoped that a poll of this kind can be useful in a variety of ways. Even though most governors, in comparison with Presidents, barely penetrate the historical consciousness, it still is helpful to find which governors in a particular state like Arkansas have captured some historical attention and why. Since professional historical research in Arkansas has not been extensive, a poll may identify areas, individuals, and historical periods where further investigation is needed. It also can provide a reference point for the future, since the consensus reached in 1980 on governors will undoubtedly be substantially revised by 2020 .

The Schlesinger model does present certain problems, however, when it is applied to a state. Each one of the Presidents in the "great" category seems to have interpreted the powers of his office broadly and left the office greatly strengthened after his departure. ${ }^{1}$ This kind of achievement is difficult for a governor of a Southern state with a Reconstruction constitution even 
to approach, because the legal powers of the office are usually carefully circumscribed. The ambiguity of the United States Constitution that allows Presidents to read their powers liberally is not present in the 1874 Arkansas Constitution. In fact, the Arkansas Constitution may so severly limit the governor that the likelihood of one of them having a significant impact on history and events is greatly reduced."

All of the Presidents in the "great" category in the Schlesinger polls of 1948 and 1962 were "activist" Presidents. The Arkansas poll should give some interesting comparisons as to whether this same judgment is made at the state level, particularly in view of Watergate and a consequent climate of opinion more favorable toward restricting the powers of the Presidency. Will a "Whig" type governor who emphasizes dignity, honor, and restraint at the expense of significant political achievements rank higher in this post-Watergate era, or will the emphasis still be placed by the panelists upon the activist who achieves concrete political results? Are attitudes any different at the state level in regard to executive power today, or is it still an unsolved dilemma "between the people's fear of executive power and their confidence in its necessity and capacity for good"? ${ }^{3}$

Before discussing the mechanics of this Arkansas poll, some historical background on the office of governor in the state will help put the office in perspective. Under the 1868, or Reconstruction, Constitution in Arkansas, the governor was elected for a four year term with a salary set by the legislature. The Republican Party, then new to the state, attempted during Reconstruction to establish a centralized state government because "it did not have the local organizations to carry out its functions throughout the state." 4 One method used to accomplish this centralization was to increase the appointing power of the governor, and his appointing powers under the 1868 Constitution were breathtaking. ${ }^{5}$ The governor appointed the tax assessors, prosecuting attorneys, all judges in the state with the exception of supreme court judges, and all precinct and township officials. With the return of Democratic rule in 1873 , the inevitable reaction occurred; under the new constitution 
approved in 1874, the term of office was cut from four to two years, the salary was set in the constitution itself, and the powers of appointment were cut back sharply.

The office as delineated in the 1874 Constitution is relatively unchanged today. The governor has a two year term, the salary is still set in the constitution, and any veto can be overridden by a majority vote of the legislature. The governor shares executive power with six other elected executive officials and numerous independent boards and commissions. Two of these independent agencies, the Highway Commission and the Game and Fish Commission, not only are administratively independent by constitutional amendment ${ }^{6}$ but are fiscally autonomous as well, since their operating revenues are generated by special taxes (gasoline and hunting and fishing licenses) earmarked for highway and wildlife purposes.

Even though constitutional and legal powers define only one dimension of a governor's office, this dimension is important because the governor's lack of strong legal and constitutional powers can inhibit great accomplishments in office and cause low historical ratings. As described by the Arkansas Constitutional Revision Study Commission in 1968:

Presently Arkansas' governors do not have constitutional powers commonly associated with the concept of "chief executive," although many have had great influence as political leaders. . . Short term of office, weak veto, meager salary, competing and independently elected executives at the State level, and a proliferation of agencies subject to little executive control have significant bearing on gubernatorial influence both in policy matters and in administrative management. These and other limitations hinder the ability of a governor to fulfill public expectations for responsible accomplishment of programs for which he has received a recent popular mandate. ${ }^{7}$

In choosing the respondents for the Arkansas Governors Poll, an attempt was made to include experts who had taught, published, or shown an unusual interest in Arkansas history and government. Although most of the individuals asked to 
participate were college teachers, the group included journalists, political advisors, and others with expertise in this area even though not necessarily engaged in teaching or research. ${ }^{8}$ Forty-one responses were received from a mailing of fifty-three - a return rate of 78 per cent. The Schlesinger model was used, in that evaluation was based on only what a governor did while in office, and evaluation standards were suggested for use by the respondents. ${ }^{9}$ The poll included only governors since 1900 in order to limit evaluation to sixteen governors rather than to a total of forty, which would be the case if 1819 (the year Arkansas became a territory) were selected. In addition to making a respondent's task more manageable, beginning the poll in 1900 focuses attention on an historical period nationally, a time when executive leadership at the state level became increasingly active and the policy making role of the governor became more visible. Governors who served less than a year or who had been out of office for less than ten years were not considered. At the suggestion of the respondents, Governor John S. Little, who served only several months before his health failed, was also excluded from the poll.

Respondents were asked to rank governors of Arkansas since 1900 on a five point scale with five given for great, four for good, three for average, two for below average, and one for poor. ${ }^{10}$ The authors established the following categories and necessary ranking: great -5.0 to 4.5 , good -4.4 to 3.5 , average 3.4 to 2.5 , below average -2.4 to 1.5 , poor -1.4 and below. A governor's rank in the poll was determined by dividing the total points which he received by the number of respondents who chose to evaluate him. Written comments on the governors were encouraged.

The poll results are shown in Table One. Each governor is listed by rank and category. Table One shows total points obtained as well as the number of individuals who evaluated each governor. 


\section{Table One}

Arkansas Govenors in the Twentieth Century

$\begin{array}{llllr}\text { Charles H. Brough } & 31 & 4.16 & \text { Good } & 129 \\ \text { George W. Donaghey } & 29 & 4.10 & \text { Good } & 119 \\ \text { Winthrop Rockefeller } & 35 & 3.97 & \text { Good } & 139 \\ \text { Sid Mc Math } & 35 & 3.86 & \text { Good } & 135 \\ \text { Carl E. Bailey } & 31 & 3.74 & \text { Good } & 116 \\ \text { Thomas C. McRae } & 27 & 3.56 & \text { Good } & 96 \\ \text { Ben T. Laney } & 33 & 3.33 & \text { Average } & 110 \\ \text { John E. Martineau } & 24 & 3.21 & \text { Average } & 77 \\ \text { Jeff Davis } & 27 & 3.15 & \text { Average } & 85 \\ \text { Orval Faubus } & 34 & 3.12 & \text { Average } & 106 \\ \text { George W. Hays } & 24 & 2.88 & \text { Average } & 69 \\ \text { Francis Cherry } & 35 & 2.83 & \text { Average } & 99 \\ \text { Homer M. Adkins } & 30 & 2.80 & \text { Average } & 84 \\ \text { J.M. Futrell } & 29 & 2.76 & \text { Average } & 80 \\ \text { Harvey Parnell } & 29 & 2.59 & \text { Average } & 75 \\ \text { Tom J. Terral } & 24 & 2.04 & \text { Below } & 49 \\ & & & \text { Average } & \end{array}$

Number of

Respondents Ranking Category

Charles H. Brough

George W. Donaghey

Winthrop Rockefeller

Sid McMath

Carl E. Bailey

Thomas C. McRae

tineau

Jeff Davis

Orval Faubus

George

Francis Cherry

Homer M. Adkins

53 Questionnaires Mailed

35 Responses by Questionnaires

${ }_{6}$ Responses by Letter
Total

Points

129

119

39

16

96

77

85

06

69

99

84

80

75

49

\section{Background and Analysis ${ }^{11}$}

The seventy years served by the Arkansas governors in the poll roughly correspond to three periods in American history: the progressive era (1900-1920); the period-between-the-wars (1920-1940), and the post-World War II period (1945-1970). Each period had its own distinctive characteristics nationally, and some discussion of these periods may be helpful in identifying a particular Arkansas governor with that period of American history during which he served and to see the impact of national trends on a state administration.

The progressive era was held together by a fairly sophisticated reform movement which showed three major tendencies. Politically, the reformers wanted to eliminate graft, corruption and "boss rule" while making the political process more open 
and responsive to the general public. Economically, progressives sought to break up corporate monopoly where necessary, regulate business activities wherever possible, and foster competition when there was an opportunity to do so. Socially, leaders of the period worked for improving conditions of the poor, including better education, health care and housing; eliminating child labor and securing voting rights for women. It was a time when public opinion generally supported the concept of a strong president and vigorous executive leadership. Governors Jeff Davis, George Donaghey, George Hays, and Charles Brough all served during the progressive era.

The second historical era, the period-between-the-wars, can be almost equally divided into two sections of ten years each. The 1920's witnessed the flowering of American business as increasing world trade, an expanding domestic market and lack of governmental interference combined to produce a decade of prosperity. Gone was the progressive spirit of reform and regulation. Instead, a mood of laissez-faire prevailed, perhaps best illustrated by President Calvin Coolidge's statement that "the business of government is business."

The 1930's brought a reversal in both political and economic trends. From an economic stand point, the decade was a time of depression characterized by high unemployment, sluggish capital expansion and general pessimism. Politically, however, it was one of the most active decades in United States history. President Franklin D. Roosevelt, with personality and programs, led the Congress in implementing a broad-based plan to ease if not break the economic stagnation. Thomas McRae, Tom Terral, John Martineau, Harvey Parnell, J. M. Futrell, Carl Bailey, and Homer Adkins held office in Arkansas during the period-between-the-wars.

The post World War II era has been characterized by A merica's growing involvement in world affairs. The Cold War caused the nation's political leaders to seek alliances around the world and stock pile nuclear weapons. Defense spending became an integral, essential part of the budget. Domestically, Americans came to be increasingly concerned with civil rights in general and minority rights in particular. The domestic econ- 
omy, spurred by international trade, an expanding home market, and a rapidly increasing population, provided businessmen with a new wave of prosperity. Ben Laney, Sid McMath, Frances Cherry, Orval Faubus, and Winthrop Rockefeller were the Arkansas governors during this time.

Of the top five governors in the poll (Brough, Donaghey, Rockefeller, McMath, McRae), two served during the progressive era when the national mood was reformist in tone, two served in the post-World War II period when the national emphasis was on improved race relations and industrial growth, and one served during the decade of the Great Depression (the period-between-the-wars) when concern for the problems of rural America and the poor was particularly evident. Although diverse in occupation (two businessmen, two lawyers, and one college professor), they shared several characteristics. All were strong personalities, had well conceived programs before taking office, and worked tirelessly to gain legislative approval for their ideas. That each was also sensitive to the national mood is perhaps indicative of his place in the poll.

Charles Hillman Brough (1917-1921) ranked first in the poll. Born in Mississippi, Brough came to Arkansas as a professor of economics at the University of Arkansas. His most immediate problem as governor was an acute economic crisis brought on by a severe shortage of state income. After gaining legislative approval for securing a short term loan to meet emergency needs, he then moved on a broad front to create a budget system for state government, revise the schedule for property assessments and establish a standardized accounting system for county government. On other matters, Brough called for a convention to draft a new state constitution and took the lead in movements to improve public education, eliminate adult illiteracy, adopt prohibition, and increase the availability of health services. Partially as a result of his actions, the legislature created the Arkansas Illiteracy Commission and the Textbook Commission, passed the "Bone Dry Law" for prohibiting the sale of alcoholic beverages, and established the State General Hospital to provide free health care for qualified patients. 
Brough's term coincided with Woodrow Wilson's second term as president. Both were college professors and served during the progressive era when voters supported strong and vigorous executive leadership. Wilson finished among the top five presidents in the 1962 Schlesinger poll.

George W. Donaghey (1907-1911) finished second in the rankings. A building contractor from Conway, Donaghey was elected initially because of his promise to complete the new state capitol building. He once remarked that he would rather build the capitol than be governor. His first term was almost totally devoted to the construction issue. In his second term he devoted a major portion of his attention to education, particularly in rural areas. With his leadership the legislature chartered four agricultural schools, widely separated geographically, in the effort to encourage more young people to attend school. The General Assembly also created a department of public health, established a tuberculosis sanitarium, and approved a constitutional amendment authorizing initiative and referendum petitions.

Donaghey's administration ran concurrently with William Howard Taft's tenure as president. The governor's business background was apparently more in line with voter sentiment than Taft's cautious approach toward problem solving. Taft, trained as a lawyer, took a legalistic approach toward executive leadership and finished far dow $n$ in the presidential poll in the average category.

Winthrop Rockefeller (1967-1971), a transplanted New York businessman, finished third. He first got into politics by serving as director of the Industrial Development Commission under Orval Faubus. After breaking with Faubus on the race issue, Rockefeller made an all out effort to rebuild the Republican party in the state. His activities were rewarded in 1966 when he became the first Republican governor of the state since Reconstruction. Once in office Rockefeller focused his attention on reform. He closed casino gambling in Hot Springs, made major changes in the prison system, and sponsored a bill in the legislature providing for tighter regulation of the sale of securities in the state. He also attempted to reorganize and 
consolidate state agencies, but was thwarted by the General Assembly.

Rockefeller's terms as governor came during the presidential administrations of Lyndon B. Johnson and Richard M. Nixon. Neither of these presidents was included in the Schlesinger poll.

Sid McMath (1949-1953), an attorney from Hot Springs, was fourth in the poll. He first claimed statewide attention while prosecuting attorney of Garland County. In that position he earned the reputation as being a reformer, opposed to machine politics and an advocate for equal protection under the law. As governor he continued his reform efforts by sponsoring anti-lynching legislation, repeal of the poll tax, and a new system of voter registration and a new election code. He also made a major commitment to expand the highway system. Unfortunately for his program, all of McMath's proposals except the highway proposal were defeated by the legislature. McMath was defeated while seeking a third term as governor.

McMath served as governor while Harry S. Truman was president. They held similar views on race relations and political reform. For a time McMath was rumored to be under consideration for a position in the Truman cabinet. Truman was ranked in the near great category by the Schlesinger poll.

Carl E. Bailey (1937-1941) ranked fifth in the poll. Although born in Missouri, he lived at several locations in Arkansas before opening a law office in Little Rock. As governor he inherited the highway debt problem which had plagued Arkansans for a decade. Like his predecessors he also adopted a plan for refinancing the debt. On other matters he sought to increase state services, gain legislative support for a two percent sales tax, increase support for the public schools and old age assistance, while reducing the state tax on property. The legislature also approved the first workman's compensation law during his tenure in office.

Bailey was governor during Franklin D. Roosevelt's third term as president. In the later 1930's Roosevelt's administration increasingly turned to reform in social welfare, labor and agriculture. Roosevelt finished in the top five in the Schlesinger poll 
and this put him in the great category.

Thomas C. McRae (1921-1925), an attorney from Prescott, placed sixth in the governor's poll. A fiscal conservative, he repeatedly advocated a philosophy of "make no appropriation until funds are in sight to meet it." During his four years in office he called the legislature into special session on three different occasions. But despite this political activity McRae succeeded in getting only two major programs adopted. One provided for increased funding for public schools through a special tax on cigars and cigarettes; the other established the basis, without funding, for a state highway system.

McRae was governor during the administration of Warren G. Harding and Calvin Coolidge. Both presidents were also fiscal conservatives and the national mood shifted decidedly in favor of business and away from reform. In the Schlesinger poll, Harding rated as a failure and Coolidge was listed in the below average category.

Ben T. Laney (1945-1949), a businessman from Camden, was rated as the seventh best governor by the respondents. His administration was perhaps best remembered for the Revenue Stabilization Act which Laney sponsored. The effect of this proposal was to create a single fund to operate state government and most of the state agencies. Laney also pushed for major consolidation and reorganization of the various state boards and commissions. A Public Service Commission and a Resources and Development Commission resulted from this action. Initiated Act I, which provided for major consolidation in the public school system, also became law during his administration.

Laney served as governor during the transition between Franklin Roosevelt and Harry Truman. He strongly disagreed with Truman on the race issue and led in the formation of a third party, the Dixiecrats, to oppose Truman for the presidency in 1948.

John E. Martineau (1927-1928) finished eighth in the poll. An attorney and public school teacher from Lonoke, he was elected after campaigning on a slogan of "good roads and good schools." He succeeded in at least part of his program when he persuaded the legislature to approve the "Martineau Road 
Law," which created a comprehensive road system with a continuous source of funding. The remainder of Martineau's program was cut short when President Coolidge appointed him federal judge for the eastern district of Arkansas.

Jeff Davis (1901-1907), an attorney from Russellville, finished ninth in the poll. He was the first Arkansas governor to be elected for a third term. Although in office during the progressive era in American history, Davis demonstrated no consistent pattern of reform behavior. An executive with an activist philosophy, he once vetoed some three hundred bills as a direct challenge to legislative authority. On the other hand, he sponsored no major program of his own. An outspoken critic of the convict lease system, Davis pardoned numerous prisoners. But at the same time he strongly opposed efforts by the Prison Board to acquire the Cummins Plantation, a move that would provide more space and improve conditions for inmates. Although an opponent of excessive waste and expenditures in state government, he nevertheless campaigned vigorously against efforts to build a new capitol building-even when it was apparent that the original capitol had become overcrowded and inadequate for transacting the state's business.

Other progressive measures enacted by the General Assembly during Davis' administration included a reform school for youthful offenders, a child labor law and recognizing Labor Day, the first Monday in September, as a holiday. In each instance, however, Davis' role was minimal.

Theodore Roosevelt was president at the time Davis was governor. The two men were sometimes compared because of their similar, flamboyant styles in campaigning. However, their similarities ended there. Roosevelt was a much more effective administrator than Davis. In the Schlesinger poll, Roosevelt rated in the near great category and finished seventh in a field of thirty-one.

Orval E. Faubus (1955-1967) finished tenth in the poll. A newspaper publisher from Madison County, he was elected six times and served more years as governor than any other chief executive in Arkansas. His administration may well be divided into two periods: before and after the Little Rock Central High 
school crisis. In his early years as governor, Faubus provided major assistance to public schools, welfare assistance and roads for rural areas. He also integrated the state Democratic party by appointing six blacks to the central committee. He worked closely with the Industrial Development Commission in an attempt to attract industry to the state. After the Little Rock Central High school crisis however, Faubus turned increasingly to racial issues and many of his earlier programs were deemphasized. He voluntarily retired from the governor's office after serving twelve years in that post.

Faubus' tenure as governor coincided with the presidential administrations of Dwight D. Eisenhower, John F. Kennedy and Lyndon B. Johnson. Eisenhower was the only one of three rated by the Schlesinger poll and he finished in the average category.

George W. Hays (1913-1917), a Camden attorney, placed eleventh in the poll. Initially elected to fill the unexpired term of Joe T. Robinson, Hays was then reelected for a full term in 1915. As governor he faced a growing deficit in the state treasury. In an effort to increase revenue, he tried, unsuccessfully, to get county officials to raise property assessments and thereby eliminate the need for a general tax increase. Funding for state government continued to be a problem throughout his administration. Hays was governor during Woodrow Wilson's first term as president.

Francis Cherry (1953-1955), was ranked twelfth in the poll by the respondents. Born in Texas and educated in Oklahoma, he performed a variety of jobs before opening a law practice in Little Rock. As governor he sponsored legislation to create a new fiscal code for the state that required "strict accountability" for expenditures. He also supported efforts by Arkansas Power and Light Company to gain a rate increase from the Public Service Commission and he endorsed a bill requiring that names of welfare recipients be made public. The latter two issues proved to be particularly unpopular and Cherry was denied reelection to a second term by state voters. He was only the second governor in the twentieth century to fail in such a bid. He served as governor during the transition between Dwight 
Eisenhower's first and second administration.

Homer M. Adkins (1941-1945), a pharmacist from Jacksonville, served two terms as governor during World War II and placed thirteenth in the poll. Although leading the state in the war effort, he offered little by way of legislative programs, and local politics was almost totally overshadowed by world events. Federal funds and employment opportunities in war industries greatly improved the state's economy. Even so, Arkansas received less federal funding (more than twenty-five percent less than Mississippi, the next lowest) than any other state in the South. Adkins served as governor during Franklin Roosevelt's fourth and last term as president.

J. M. Futrell (1933-1937) rated fourteenth in the poll. A public school teacher and lawyer from Greene County, Futrell was governor during the depths of the Depression. He campaigned on a platform of reducing state expenditures by fifty percent. Once in office he set out to reach that objective by ordering all state agencies to "live within their income." He also sought to have the highway indebtedness refunded and insisted that the state prison become economically self-sufficient. Futrell's austerity, coupled with a massive infusion of federal money, allowed officials to get the state's economy under control. The price paid in terms of lost services, however, worked a hardship on many Arkansans-particularly small farmers.

Futrell served as governor during Franklin D. Roosevelt's first term as president. The two men could not have been more dissimilar in either personality or executive leadership.

Harvey Parnell (1928-1933) finished fifteenth in the poll. A farmer from Dermott, he was the first Lieutenant Governor under the 1874 constitution. He assumed office during one of the most difficult periods in the state's history. The Martineau Road Law had obligated the state to an indebtedness of more than one hundred million dollars, payable in yearly installments. Unfortunately between 1927 and 1930 Arkansas suffered a cycle of devastating floods and droughts that all but destroyed the state's agriculture. That, coupled with the business depression that followed the stock market crash, severely hampered the 
economy. In an effort to meet these needs Parnell ordered a twenty percent reduction in state expenditures and twice called the legislature into special session to consider reduction in cotton acreage and highway refunding. The legislators were cooperative but all efforts did little to check the state's growing indebtedness. Parnell did not seek reelection for a second term.

Herbert Hoover was president during Parnell's tenure as governor. The two men showed much of the same philosophy about governmental responsibilities and programs in proposing solutions to the problems of the Depression. Hoover finished in the average category in the presidential poll.

Tom J. Terral (1925-1927) finished last in the poll. Born in Louisiana, he spent most of his adult life in Little Rock where he worked as an attorney. As governor he sponsored no programs of consequence and achieved only mild success in gaining additional funding for the public schools. He was the first governor in the twentieth century to seek reelection to a second term and be defeated. Terral was governor during the presidential administration of Calvin Coolidge.

On the basis of the number of respondents, Rockefeller, McMath, and Cherry were the best known of the governors. Each was evaluated by 35 of the 41 people who completed the survey. Terral, evaluated by 24 respondents, was the least known. Rockefeller received the highest number of points, 139 , based on the rating scale, and Terral with 49 , received the least number of points.

\section{Comments of Respondents}

The comment section deals only with the observations by the respondents who cared to put their thoughts about various governors in writing. Since this was usually less than half of those who evaluated a particular governor, these comments should not necessarily be read as typical of the entire group who made the evaluation. An attempt has been made to briefly summarize these comments and to quote verbatim in certain situations.

According to the respondents in the Arkansas governors' poll, the two best governors in Arkansas since 1900 were 
Charles H. Brough with a 4.16 and George W. Donaghey with a 4.10. Both governors ranked well above the midpoint (4.00) in the "good" category.

Charles H. Brough, in the opinion of the respondents, was a progressive in the Woodrow Wilson tradition of the scholarpolitician who worked for such causes as a new constitution, women's suffrage, penal reform, and administrative reorganization. Most respondents saw him as a highly intelligent and articulate person who possessed great speaking skills. The only blot on the record was his handling of the Elaine race riot. One of those offering comments about Brough seemed to catch the consensus of those who did comment when he said: "Aside from the 1919 tragedy in Elaine, Brough appears to have been a highly positive governor who was much more active than other Arkansas governors during the first half of the twentieth century."

Comments about Donaghey were not as extensive as those about Brough. Donaghey was given credit for ending the convict leasing or convict labor system and for completing construction of the state capitol and rescuing that project "from the mess in which Jeff Davis had left it." Donaghey was perceived as an able administrator and a thoroughly honest man. In fact, even though ten people made written observations about Donaghey, it is remarkable that virtually all of these were in a positive vein.

Winthrop Rockefeller got a 3.97 ranking in the poll but this verdict was more mixed than in the cases of Brough and Donaghey. He was praised for a more positive national image, more professional appointments, better race relations, and a climate of reform that valued openness and new ideas. This was offset by what many of the respondents saw as his political ineptness and limited administrative ability. The handicap of being a Republican in Arkansas and the problem that this caused in working with the legislature was also mentioned. Nevertheless, the overall evaluation was much more positive than negative. As one of the respondents put it; "Unquestionably, Arkansas is better off today as a result of Win Rockefeller 
having been governor at the particular time during which he served."

Sid McMath finished forth in the poll with a ranking of 3.86. McMath was commended for his handling of race relations, the positive national image that he projected, and the reform legislation that he supported. The consensus of those who made comments about McMath, however, was that his promise was unfulfilled because of the highway scandal and that this episode prevented a "great" ranking.

Carl E. Bailey received a ranking of 3.74 which kept him well within the range (4.4 to 3.5) of the "good" category. The respondents who saw Bailey in a favorable light mentioned as evidence of this ranking his ability as an administrator and his support for a civil service law and free textbooks through the eighth grade. He was also viewed as a governor who understood the needs of a depression era and how to meet those needs. The only negative factor stressed about Bailey was the consuming ambition that led him into mistakes of judgment such as his unsuccessful attempt to become a U.S. senator in 1937 after Joe T. Robinson's death. Bailey had the Democratic State Committee select him as their nominee rather than calling a special primary to pick the nominee. This tactic was resented and Bailey was defeated in a special election to fill Robinson's seat by John E. Miller, who ran as an independent candidate.

Thomas C. McRae was the last governor in the "good" category, and the respondents chose to make only a few observations about him. They were mostly to the effect that McRae was midly progressive for the twenties, that he favored more money for education, and began a modern road building program. He seems almost, however, to be damned with faint praise.

The next category was the one designated as "average," and, as might be expected, it contains most of the governors since 1900 . Nine governors fall in the 3.4 to 2.5 range. In this "average" category and ranked right next to each other are found Jeff Davis and Orval Faubus, the two most divisive and charismatic personalities in the seventy years covered by the poll.

Ben T. Laney was the governor with the highest ranking 
(3.33) in the "average" category. The respondents took a generally favorable attitude toward Laney pointing out that during his campaign he promised to bring a business like administration to state government and that he did what he said he would do. He was praised for his sound fiscal management and for the passage of the revenue stabilization act (an act which guarantees that the state cannot spend more money than it takes in). Most criticism of Laney focused around his attitude on race, but this seemed to be outweighed by his administrative and fiscal accomplishments. One respondent phrased it this way: "His fiscal management was superb and the revenue stabilization act was an inspired piece of legislation. This offsets his negative position on race."

John E. Martineau also ranked high (3.21) in the "average" category. Evaluation of his administration was particularly difficult since he resigned during this first term to accept a Federal judgeship. Only seven respondents wrote anything about Martineau, and their comments were almost split equally between those who said that the Martineau road program was a blessing and those who said it was disaster. The road legislation sponsored by Martineau unified the highway system in the state and provided that the state would assume the debts of the local highway improvement districts and would finance new construction through the sale of bonds. The program was caught by the flood of 1927 and the depression two years later, and hence the split verdict. The Martineau road program was almost the only thing mentioned in the evaluations.

Jeff Davis falls in the middle range of the "average" category. The consensus of those who commented was that he was more talk than action, and though perhaps possessing progressive instincts, his measurable accomplishments were few. His deeds failed to match his rhetoric and "like some of Arkansas' more contemporary politicians, Davis seemed to enjoy 'getting' elected more than experiencing the powers of office."

Ranking just below Jeff Davis was Orval Faubus at 3.12. Over half the respondents expressed their opinions about Orval Faubus, and they range over the spectrum from those who felt that he should be ranked "as a good to great governor primarily 
based upon his strength in administrative leadership and accomplishments" to some who felt that his administration was "the low point in all American history." Most evaluations however, clustered around a middle position that acknowledged Faubus' achievements (broadening the tax base, economic development, mental health efforts, state building program, and expansion of state services) but felt that they were overshadowed and outweighed by the 1957 Central High School crisis. This middle position is summarized in the following quote:

[He is] the hardest governor to evaluate due to the mixed results of his tenure. The first four years would be classified as "good." The remaining eight years are mixed. The most overwhelming impact of his administration was the tremendous adverse publicity resulting from the 1957 [Central High] school crisis. During 1958-59, Arkansas experienced a crisis which adversely effected the development of the state for a decade or more. More than anyone else, Faubus bears the responsibility for the situation which developed. Despite many positive accomplishments, the overall impact of Orval Faubus' 12 years in office can only be considered negative.

George W. Hays was ranked at the mid point (2.88) in the "average" category. Only five respondents chose to make remarks about Hays so it is difficult to get any insights into the reason for his ranking. Two respondents considered him mildly progressive because of his attempts at property tax reform while two others thought him undistinguished although very popular with the public. The fifth respondent was non-commital about Hays.

Francis Cherry was ranked below the mid point in the "average" category and there was a surprising unanimity among the respondents that Cherry was sincere and honest but also insensitive, tactless, and poorly equipped for political life. He lacked executive ability and political skills and "did such a poor job that he was defeated for a second term."

Homer Adkins, in the judgment of those who made written comments, was strictly a machine politician with little foresight 
and few ideals. He received a ranking of 2.80 which puts him well below average in the "average" category.

J. M. Futrell was praised for keeping the state from bankruptcy but criticized for his insensitivity to the needs of the people in a time of economic crisis. The consensus seemed to be that he "did good work in keeping the state from bankruptcy, but possessed the wrong economic outlook for depression times."

Harvey Parnell was the governor who is ranked last in the "average" category. Although a few of the respondents were sympathetic toward Parnell's attempts at leadership during the depression, most felt that he was simply the wrong person to cope with the staggering problems of the depression. The highway scandal during his administration was also mentioned.

Tom J. Terral was the only governor placed in the "below average" category. He drew little comment from the respondents except where it was emphasized that he was not elected to a second term.

\section{Conclusion}

Prior to preparing the questionnaire, the authors reviewed several potential problems. One concern was the extent to which respondents would be familiar with the governors. Unlike the Schlesinger Presidential Poll, which had the advantage of having well publicized subjects and a broad national sample, Arkansas governors have not, traditionally, received a great deal of attention. Also, the governor's survey involved fewer subjects, sixteen, and there was a smaller reservoir of individuals to poll than in the Schlesinger Presidential Poll. As anticipated, respondents were generally less familiar with those individuals serving prior to World War II. If respondents' comments were any guide, however, governors during the progressive era were reasonably well known. Clearly respondents were less familiar with chief executives of the 1920's and 1930's.

Another concern was the extent to which the post-Vietnam, post-Watergate distrust of executive power would influence the ratings. Specifically, the question was raised as to whether or not a governor might be penalized for an activist administration. This concern proved unfounded, as reflected in the fact 
that the top four governors were all activists in terms of legislative program and political action. The least active governor also received the lowest ratings.

There was also a curiosity as to whether any governor would be ranked in the "great" category. In preparing the guidelines the authors determined that to be considered "great" a governor must receive a "great" ranking from at least fifty percent of the respondents. While that formula appears to be a most lenient one, in reality none of the governors achieved a ranking of great. Perhaps the primary reason behind this lack of distinction is reflected in a comment on one of the questionnaires. As the respondent noted, the "conservative nature of the legislature and the frequency of gubernatorial elections made it difficult for any Arkansas governor to be rated great." It is also possible that the office, created during Reconstruction when distrust of executive power was prevalent, simply lacks the constitutional authority and broad legal powers that can enhance the place in history of a talented governor.

Finally, as many respondents noted, there is a great need for more research on Arkansas governors-both on the office and the individual governors. The governor's role in federalstate relations, regional planning, and economic development, to name just a few areas, has been largely unexplored by the state's academic community. A systematic evaluation of individual issues such as education, the prison system, the highway program, and race relations, among others, has also been neglected by researchers in terms of executive leadership. Perhaps this poll will have the effect of focusing more attention on the governor's office in the future. At least it offers an opportunity to establish a bench mark for evaluating the state's chief executives eight decades into the twentieth century. 


\section{Notes}

1. Arthur M. Schlesinger. "()ur Presidents: A Rating by 75 Historians," New York Times Magazine, 29 July 1962 , p. 41.

2. See Ark. Const. Art. VI (1874).

3. Louis Koenig. The Chief Fxecutive, 3rd ed. (New York: Harcourt. Brace, Jovanovich, 1975). p. 34.

4. Ralph ('. Barnhart, "A New Constitution for Arkansas," Arkansas Law Review XVII (Winter 196i2-6.3), p. 3.

5. Ark. Const. Art. $8(1868)$.

fi. Ark. (onst. (1874). A mend. 35 (1944) and 42 (1952).

7. Arkansas Constitutional Revision Study Commission. Revising the Arkansas Constitution (little Rock, 1868), p. 56.

8. The persons who were asked to participate, their occupations, and affiliations are given below. (For occupations. $\mathrm{H}=$ Historian. $\mathrm{J}=$ Journalist, $\mathrm{PS}=$ Political Scientist. $\mathrm{L}=$ = Lawyer. $\mathrm{C}=($ Citizen.)

Kenneth Walker
Michael Dougan
J. E. (iriner

\section{Ray Muncy}

Boyce Drummond

(ieorge Thompson

Robert Meriwether

Richard Yates

Daniel (irant

Bob Riley

Robert Johnston

William C. Nolan

Robert Waltz.

Walter Brown

Diane Kincaid Blair

Don Holley

Henry Wilkins

Waddy Moore

Foy Lisenby

Simms McClintock

John Ferguson

Marcus Halbrook

Henry Woods

Walter Nunn

Kay (ioss

Willard Ciatewood

Tom Dillard

Norman Hodges

Robert Leflar

Leland Duvall

Margaret Ross

Robert McCord

Harry Ashmore

Jim Lester

John Ward

Mary Hudgins

Bob Lancaster

Ernest Dumas

Brooks Hays

Boyd Johnson
H

$\mathrm{H}$

PS

$\mathrm{H}$

$\mathrm{H}$

$\mathrm{H}$

PS

PS

PS

PS

PS

PS

$\mathrm{H}$

H

PS

$\mathrm{H}$

PS

$\mathrm{H}$

H

PS

H

C

L.

PS

PS

H

$\mathrm{H}$

PS

L.

J

J

J

J

H

J

C

J

J

C

H
Arkansas Tech University

Arkansas State University

Arkansas State University

(iarland County Community College

(part-time)

Harding University

Henderson State University

Hendrix College

Hendrix College

Hendrix College

Ouachita Baptist University

Ouachita Baptist University

University of Arkansas at Little Rock

Southern Arkansas University

Southern Arkansas University

University of Arkansas. Fayetteville

University of Arkansas, Fayetteville

University of Arkansas at Monticello

University of Arkansas at Pine Bluff

University of Central Arkansas

University of Central Arkansas

University of Central Arkansas

Arkansas History Commission

Director of Arkansas Legislative Council

U.S. District Judge

Arkansas Institute of Politics

\& Government

Constitutional Convention Research

Director

University of Arkansas. Fayetteville

State Parks \& Tourism

Southwest Missouri State University

University of Arkansas, Fayetteville.

Law School

Arkansas Gazette

Arkansas Gazette

Arkansas Democrat

Center for Democratic Studies. California

University of Arkansas at Little Rock

(part time)

Iog Cabin Democrat - Conway

Citizen - Hot Springs

Arkansas Democrat

Arkansas Gazette

Citizen - Chevy Chase, Maryland

Retired - Henderson State 
Dan Durning

Dale Enoch

Sam Harris

Bill Smith

Pauline Hoeltzel

Hal Douglas

Page Muhollan

Harri Baker

(ieorge Douthit

Elsie Jane Roy

Cal Ledbetter. Jr.

C. Fred Williams

\section{C}

J

C

C,

J

H

$\mathrm{H}$

J

I.

PS

$\mathrm{H}$
University of Arkansas at Little Rock (part-time)

Citizen - Little Rock

Arkansas (iazetle

Citizen - Little Rock

Citizen - little Rock

Northwest Arkansas Times - Fayetteville

Arizona State. Tempe

University of Arkansas at little Rock

Arkansas Democrat

U.S. District Judge

University of Arkansas at little Rock

University of Arkansas at Little Rock

9. Respondents were given these suggested guidelines for use in evaluating Arkansas governors: (1) Did he have a sense of history? (2) What did he achieve as governor? (3) What kind of people did he appoint to office? (4) What kind of leadership did he provide? (5) Was any significant corruption associated with his administration? (6) Did he abuse the power of his office? (7) How did his program fare with the lexislature? (8) What was his impact on the state and the office of governor? (9) [Did he use the power of his office to advance the public welfare? (10) What kind of national image did he project for the state? (11) What kind of administrative ability did he have? (12) How sensitive was he to human needs? (13) Other - please specify.

10. A copy of the instructions and questionnaire will be furnished upon request to either author at this address: University of Arkansas at Little Rock, 33rd and University. Little Rock. Arkansas 72204 .

11. The following works on Arkansas history served as principal sources for the Background and Analysis section of this paper: Dallas T. Herndon. Centennial History of Arkansas (little Ruck. 1922); John L. Ferguson and James H. Atkinson, Historic Arkansas (Little Rock. 1966): (). E. McKnight and Boyd Johnson. The Arkansas Story (Oklahoma City, 1955): Walter S. Mc Nutt. A History of Arkansas (Little Rock, 1933): David Yancy Thomas, Arkansas and Its People: A History, 1541-1930 (New York, 1930): Janice Wegener(ed.) Historical Report of the Secretary of State, (Little Rock. 1978). 